\title{
PRIMARY EPITHELIOID HEMANGIOENDOTHELIOMA ARISING AT VULVA: A CASE REPORT
}

\author{
Hyun-Seung Lee, MD', Ji-Hyun Ahn, MD², Mun-Hwi Lee, MD³ \\ ${ }^{1}$ Department of Pathology, Yangji General Hospital, Seoul; Departments of ${ }^{2}$ Pathology, ${ }^{3}$ Gynecology, Cheju Halla General Hospital, Jeju, Korea
}

Vulvar epithelioid hemangioendothelioma as primary site is extremely rare tumor that may be confused with other mesenchymal tumors due to their rarity and its histologic features. We report a case of 46-year-old woman who presented to hospital with left vulvar mass. The mass was located in subcutaneous area of vulva, and well marginated contrast enhanced on radiologic examination. Local excision was performed. After surgery, she has remained free of disease without recurrence for 6 months. Here we report a case of primary vulvar epithelioid hemangioendothelioma as very rare site and this is the first case in Korea.

Keywords: Epithelioid hemangioendothelioma; Vulvar neoplasm; Sarcoma

Epithelioid hemangiendothelioma is a relatively rare soft tissue tumor, and intermediate malignant vascular tumor. This epithelioid angicentric vascular tumor can occur at almost any age, especially middle-aged patients, but rarely occurs in childhood [1,2]. Epithelioid hemangiendothelioma is mainly solitary, arising in superficial or deep soft tissue, and also occurs in the lung, bone, pleura, liver, peritoneum, lymph node, etc. [3], but case in the vulva is extremely rare. Only one case has been reported in the literature [4]. Here we report a case of primary vulvar hemangioendothelioma as very rare site in 46-year-old women and discuss the clinical and histologic features.

\section{Case Report}

A 46-year-old female was admitted to our hospital because of left vulvar mass that had developed during approximately 1.5 years. The patient had no specific other history including the familial history, and good general status. Computerized tomography (CT) scan showed well marginated contrast enhanced mass, measuring $2.2 \times 1.5 \mathrm{~cm}$, on vulva, and the mass was not adhered and infiltrative around surrounding tissue (Fig. 1).

Local excision was performed. The mass was well circumscribed nodular lesion in the subcutis (Fig. 2A), and showed yellow soft cut surface with focally myxoid areas. Because the mass resembled lipoma grossly, we could not offer hint of its vascular origin on gross inspection (Fig. 2B). On light microscopic examination, the tumor had two different intermingled patterns by high cellularity and myxoid area. Epithelioid cells were prominent in high cellular area (Fig. 3A). Intracytoplasmic lumina were sometimes present (Fig. 3B). These findings supported the notion that histologically epithelioid soft tissue tumor arising from vessel. Surgical resected margin involvement was present, but currently evidence of tumor recurrence is not shown during 6 months.

\section{Discussion}

The hemangioendothelioma has become a designation for those was vascular tumors which histologic intermediate in appearance

\footnotetext{
Received: 2012.2.20. Revised: 2012.5.1. Accepted: 2012.6.11.

Corresponding author: Hyun-Seung Lee, MD

Department of Pathology, Yangji General Hospital, 1636

Nambusunhwan-ro, Gwanak-gu, Seoul 151-852, Korea

Tel: +82-70-7410-9108 Fax: +82-2-879-1610

E-mail: laghonda@naver.com
} This is an Open Access article distributed under the terms of the Creative Commons
Attribution Non-Commercial License (http://creativecommons.org/licenses/
by-nc/3.0/) which permits unrestricted non-commercial use, distribution, and
reproduction in any medium, provided the original work is properly cited.

Copyright @ 2012. Korean Society of Obstetrics and Gynecology 


\section{KOREAN JOURNAL OF OBSTETRICS \& GYNECOLOGY}

Hyun-Seung Lee, et al. Vulvar epithelioid hemangioendothelioma

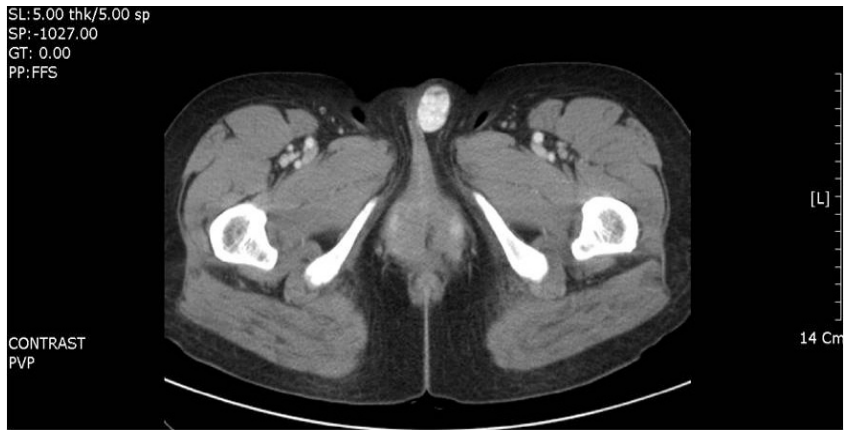

Fig. 1. Computerized tomography shows well marginated contrast enhanced mass, measuring $2.2 \times 1.5 \mathrm{~cm}$ in sized, on subcutaneous portion of left vulvar area. between a hemangioma and a conventional angiosarcoma [5]. Currently, its preferred use is for vascular tumors of an endothelial nature that occupy intermediate position between the benign hemangioma and the full-brown angiosarcoma [6].

The case of epithelioid hemangioendothelioma is relatively rare and, furthermore, has reported only one case arising in vulva as primary site at previous literature. da Silva et al. [4] have reported the first case of vulvar epithelioid hemangioendothelioma, and not reported any case in Korea.

Epithelioid hemangioendothelioma shows typically infiltrative growth pattern. However, purely cutaneous tumors often consist of a fairly circumscribed dermal tumor [2]. Our case also consists
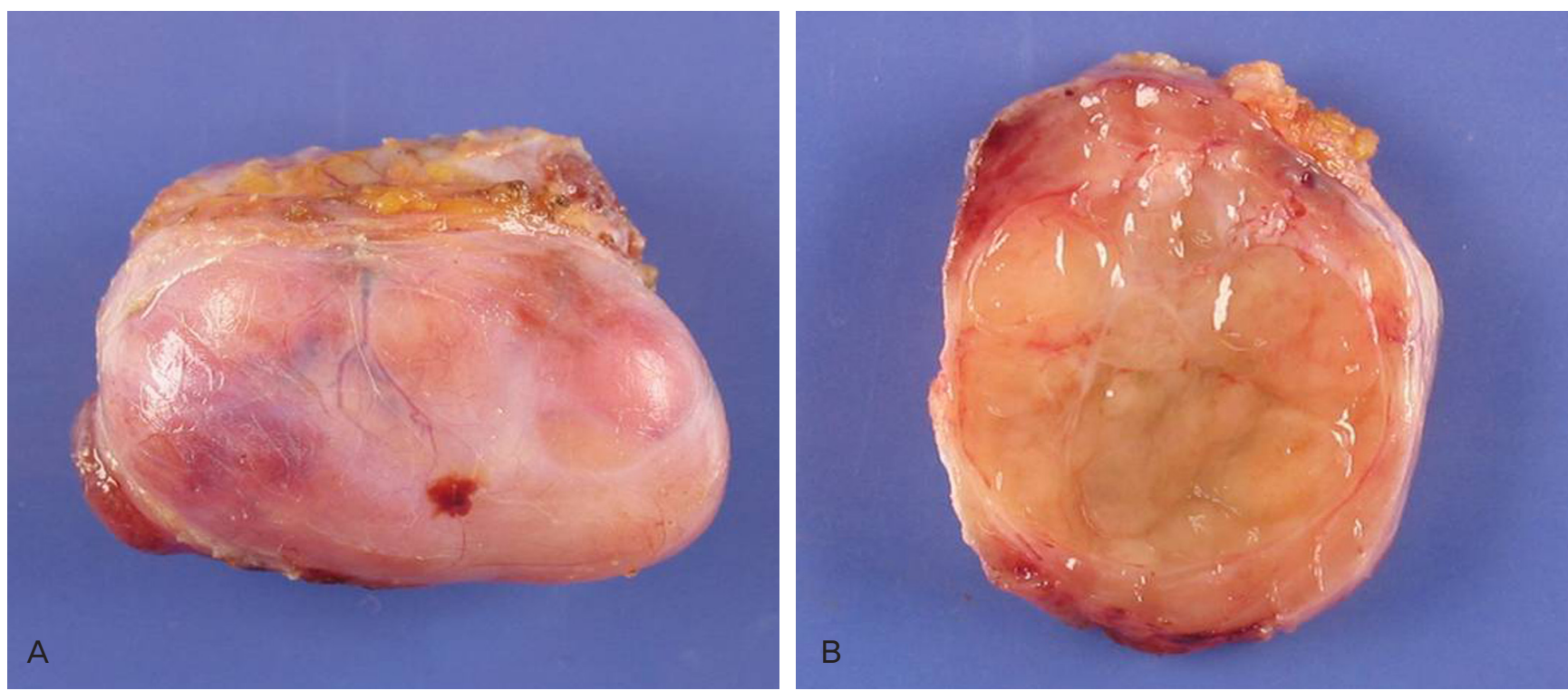

Fig. 2. Gross appearance of epithelioid hemangioendothelioma. Note a well-circumscribed nodule (A) with tan yellow soft, focally myxoid, lipoma-like gross cut surface (B).
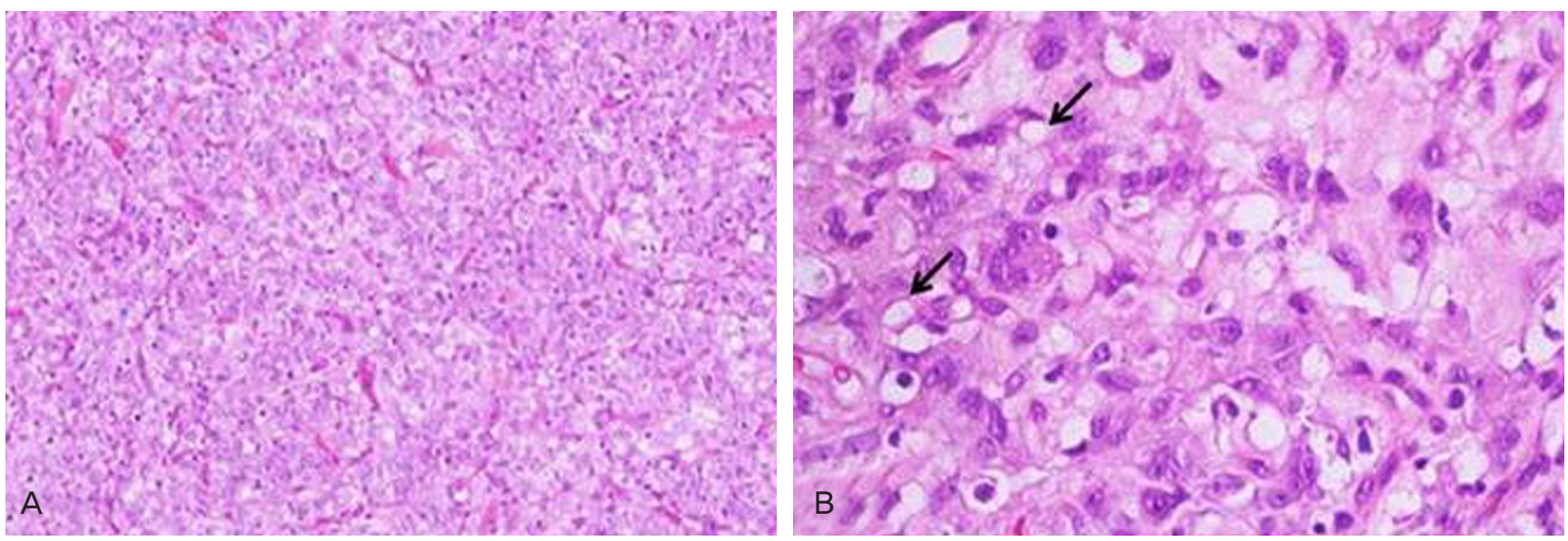

Fig. 3. Light microscopic findings show epithelioid tumor cells with variable atypia organized in nests and hyalinized stroma $(A, H \& E, \times 400)$ and tumor cells having intracytoplasmic vacuolation (arrows) $(B, H \& E, \times 400)$. 
of well-circumscribed mass, and shows yellow soft cut surface. This gross finding presents no information of vascular nature, rather requires the discrimination of lipoma and does not offer the hint of vascular originated tumor.

Differential diagnosis includes metastatic carcinoma or melanoma as well as various mesemchymal tumors because of cytologic morphology of epithelioid features. Metastatic carcinomas or melanoma can be distinguished with far more nuclear atypia and mitotic activity than the epithelioid hemangioendothelioma and rarely angiocentric. Epithelioid forms of angiosarcoma may occasionally give rise to confuse diagnosis too. The low mitotic activity (<5/50 HPF), minimal pleomorphism, lack of necrosis and the presence of intracytoplasmic vascular lumen formation should distinguish epithelioid hemangioendothelioma from epithelioid sarcoma [7]. Epithelioid hemangioma should be considered in differential diagnosis $[2,7,8]$. Epithelioid hemangioma often has a lobular architecture, prominent inflammation, and numerous wellformed blood vessels.

The stroma of epithelioid hemangioendothelioma may have a prominent myxoid appearance. The mesenchymal tumors of myxoid appearance from vulva must be contained as differential diagnosis; aggressive angiomyxoma, angiomyofibroblastoma, fibroepithelial polyp (so-called pseudosarcoma botryoides) and superficial angiomyxoma $[9,10]$.

Because the cytology prior to the surgical treatment cannot always confirm the malignant character, the treatment of choice is the complete local excision of the tumor with or without regional lymphadenectomy [11]. However, as epithelioid hemangioendothelioma is rare and almost always discovered after surgical excision for a supposed benign cause, few patients have undergone complete preoperative investigation to detect the presence of possible metastasis [12]. In addition, it has been reported that possible metastasis might not become evident for many years because of the slow growth of this tumor [12]. Our patient also was thought as probably benign tumor and so underwent local excision only. Furthermore, at microscopic discriptions, resected margin involvement was present. She is currently free from recurrence for 6 months, but further prognosis cannot be known. We will continuously follow up and observe our patient because of uncertain prognosis and presence of resected margin involvement. The role of adjuvant chemotherapy remains unclear. Läuffer et al. [13] and Makhlouf et al. [14] performed adjuvant chemotherapy with hepatic intraarterial 5-fluorouracil, radiotherapy, and/or treatment with interferon- $\alpha-2$ in cases of epithelioid hemangioendothelioma of the liver. However, the result remained unclear, since the small number of treated cases and the unpredictable evolution of epithelioid hemangioendothelioma does not permit conclusions to be drawn $[13,14]$.

In conclusion, epithelioid hemangioendothelioma is a very rare mesemchymal tumor as primary site of vulva. On gross inspections, it is difficult of doubting vascular-originated tumor, and due to epithelioid feature and myxoid stroma, many other mesenchymal tumors can be included as differential diagnosis. If pathologic confirmation is done appropriately, regular follow-up must be performed after wide resection.

\section{References}

1. De Young BR, Wick MR, Fitzgibbon JF, Sirgi KE, Swanson PE. CD31: an immunospecific marker for endothelial differentiation in human neoplasm. Appl Immunohistochem 1993;1:97100.

2. Elder DE, Elentitsas R, Johnson BL, Murphy GF, Xu X. Lever's histopathology of the skin. 9th ed. Philadelphia (PA): Lippincott Williams \& Wilkins; 2005.

3. Yousem SA, Hochholzer L. Unusual thoracic manifestations of epithelioid hemangioendothelioma. Arch Pathol Lab Med 1987;111:459-63.

4. da Silva BB, Lopes-Costa PV, Furtado-Veloso AM, Borges RS. Vulvar epithelioid hemangioendothelioma. Gynecol Oncol 2007; 105:539-41.

5. Enzinger FM, Weiss SW. Soft tissue tumors. 3rd ed. St. Louis (MO): Mosby; 1995.

6. Angervall L, Kindblom LG, Karlsson K, Stener B. Atypical hemangioendothelioma of venous origin. A clinicopathologic, angiographic, immunohistochemical, and ultrastructural study of two endothelial tumors within the concept of histiocytoid hemangioma. Am J Surg Pathol 1985;9:504-16.

7. Naqvi J, Ordonez NG, Luna MA, Williams MD, Weber RS, ElNaggar AK. Epithelioid hemangioendothelioma of the head and neck: role of podoplanin in the differential diagnosis. Head Neck Pathol 2008;2:25-30.

8. Kabukçuoğlu F, Kabukçuoğlu Y, Livaoğlu A, Ozağari A, , Armagan R, Kuzgun U. Epithelioid hemangioendothelioma of bone. Acta Orthop Traumatol Turc 2006;40:324-8.

9. Granter SR, Nucci MR, Fletcher CD. Aggressive angiomyxoma: reappraisal of its relationship to angiomyofibroblastoma in a series of 16 cases. Histopathology 1997;30:3-10.

10. Nucci MR, Granter SR, Fletcher CD. Cellular angiofibroma: a 


\section{KOREAN JOURNAL OF OBSTETRICS \& GYNECOLOGY}

Hyun-Seung Lee, et al. Vulvar epithelioid hemangioendothelioma

benign neoplasm distinct from angiomyofibroblastoma and spindle cell lipoma. Am J Surg Pathol 1997;21:636-44.

11. Gherman CD, Fodor D. Epithelioid hemangioendothelioma of the forearm with radius involvement: case report. Diagn Pathol 2011;6:120.

12. Al-Faky YH, Al Malki S, Raddaoui E. Hemangioendothelioma of the eyelid can mimic chalazion. Oman J Ophthalmol
2011;4:142-3.

13. Läuffer JM, Zimmermann $A$, Krähenbühl L, Triller J, Baer HU. Epithelioid hemangioendothelioma of the liver: a rare hepatic tumor. Cancer 1996;78:2318-27.

14. Makhlouf HR, Ishak KG, Goodman ZD. Epithelioid hemangioendothelioma of the liver: a clinicopathologic study of 137 cases. Cancer 1999;85:562-82.

\section{외음부에서 발생한 유상피성 혈관내피종: 증례보고}

${ }^{1}$ 양지종합병원 병리과, 제주한라병원 ${ }^{2}$ 병리과, ${ }^{3}$ 산부인과

이현승, 안지현 ${ }^{2}$, 이문휘 ${ }^{3}$

유상피성 혈관내피종은 혈관에서 기원한 양성과 악성의 중간에 위치한 종양으로 비교적 흔한 암종은 아니다. 종양의 대부분은 주로 단 발성으로 표재성 또는 심부 연부조직에서 발생하며 폐, 골, 흉막, 간, 복막, 림프절 등 다양한 내부기관에서도 발생할 수 있다. 외음부에서 발생한 유상피성 혈관내피종은 매우 드물며, 현재까지 국외에서 1 예의 환자가 보고되었다. 46세의 본 경우의 환자는 좌측 외음부에서 발 생한 종괴로 절제 생검을 시행하였다. 환자는 절제 후 특별한 재발의 증거는 관찰되지 않았으며 6개월간 추적 관찰 중이다.

중심단어: 유상피성 혈관내피종, 외음부, 육종 